prevent weight gain when the wires are removed is necessary. ${ }^{14}$

Probably the main obstacle to successfully treating obesity is the social attitudes of obese patients and their doctors. Severely obese people often have low self esteem and excessively optimistic expectations of each new treatment. This attitude sets traps for the doctor, who may say that the problem is trivial or easily solved or incurable, none of which is true. Virtually all obese patients can be restored to normal body composition by a normal reducing diet, but this takes time, patience, and an intelligent application of the laws of thermodynamics.

Rank Professor of Human Nutrition,

J S GARROW

St Bartholomew's and Royal London Medical Colleges,

London EC1M 6BQ

1 Garrow JS. Obesity and related diseases. London: Churchill Livingstone, 1988.

2 Rissanen A, Heliovaara $M$, Knekt P, Reunanen A, Aromaa A, Maatela J. Risk of disability and mortality due to overweight in a Finnish population. BM7 1990;301:835-6.

3 Sims EAH, Danforth E Jr, Horton ES, Bray GA, Glennon JA, Salans LB. Endocrine and metabolic effects of experimental obesity in man. Recent Prog Horm Res 1973;29:457-96.
4 Rebuffé-Scrive M, Anderson B, Olbe L, Bjorntorp P. Metabolism of adipose tissue in intraabdominal depots in severely obese men and women. Metabolism 1990;39:1021-5.

Gregory J, Foster $\mathrm{K}$, Tyler $\mathrm{H}$, Wiseman $\mathrm{M}$. The dietary and nutritional suriey of British adults. London: HMSO, 1990.

6 Garrow JS, Webster JD. Effects on weight and metabolic rate of obese women of a $3.4 \mathrm{MJ}(800 \mathrm{kcal})$ diet. Lancet 1989;i:1429-31.

(19)

8 Rigaud D, Ryttig KR, Angel LA, Apfelbaum M. Overweight treated with energy restriction and a dietary fibre supplement: a 6-month randomised double-blind, placebo-controlled trial.

9 Guy-Grand B, Apfelbaum M, Crepaldi G, Gries A, Lefebvre P, Turner P. International trials of long-term dexfenfluramine in obesity. Lancet 1989;ii:1142-5.

10 Weststrate JA, Weys P, Poortvliet E, Deurenberg P, Hautvast JGVA. Lack of systematic sustained affect of prolonged exercise bouts on resting metabolic rate in fasting subjects. Eur $\mathcal{f}$ Clin Nutr 1990;44:91-7.

11 Goldberg GR, Prentice AM, Davies HL, Murgatroyd PR. Residual effect of graded levels of exercise on metabolic rate. Eur f Clin Nutr 1990;44:99-105.

12 Mulligan K, Butterfield GE. Discrepancies between energy intake and energy expenditure in physically active women. Br 7 Nutr 1990;64:23-36.

13 Committee on Medical Aspects of Food Policy. The use of very-low-calorie diets in obesity. London: HMSO, 1987.

14 Garrow JS. Treatment of morbid obesity by non-surgical means: diet, drugs, behaviour modification, exercise. Gastroenterol Clin North Am 1987;16:443-9.

15 McFarland RJ, Grundy A, Gazet JC, Pilkington RJE. The intragastric balloon: a novel idea proved ineffective. Br $\mathcal{F}$ Surg 1987;74:137-9.

16 Kirby DF, Wade JB, Mills PR, et al. A prospective assessment of the Garren-Edwards gastric bubble and bariatric surgery in the treatment of morbid obesity. Am Surg 1990;56:575-80.

17 Larsen F. Psychosocial function before and after gastric banding surgery for morbid obesity. Acta Psychiatr Scand 1990;82(suppl 259):1-57.

\title{
Coffee, cholesterol, and coronary heart disease
}

\section{The secret is in the brewing}

Much has happened in the past decade of "coffee studies," and a new consensus has emerged. It is that drinking coffee brewed by mixing coffee grounds with hot or boiling water raises the serum cholesterol concentration, an effect that is substantially reduced by filtering. On the basis of a review of 24 cross sectional studies Bak has estimated that for every daily cup of filtered coffee consumed the total cholesterol concentration increases by $0.008 \mathrm{mmol} / \mathrm{l}$ (hardly of clinical significance). The corresponding figure for boiled, unfiltered coffee is $0.038 \mathrm{mmol} / 1$.

Fewer studies have been made of the cholesterol raising effects of coffee, and only the most recent have taken the method of brewing into account. Once again, drinking filtered coffee hardly raised the serum cholesterol concentration, ${ }^{2-4}$ whereas drinking four to six cups of unfiltered coffee a day was associated with an increase of total cholesterol of $0.50 \mathrm{mmol} / \mathrm{l}$ (higher than would have been predicted from the cross sectional studies).$^{+5}$

Extending the idea that coffee contains a lipid raising factor was the work of Zock et al. ${ }^{6}$ They heated 13501 of water to boiling point in $150 \mathrm{l}$ aliquots with $15 \mathrm{~kg}$ of coarsely ground coffee in each aliquot. (This may be the largest amount of coffee ever brewed on one occasion.) After centrifugation a lipid rich supernatant was collected and given to 10 volunteers, mixed with their meals, for six weeks. They consumed the equivalent lipid content of 6-7 cups of boiled coffee each day. During the study the volunteers' low density lipoprotein cholesterol concentration increased by $0.85 \mathrm{mmol} / \mathrm{l}$, consistent with the findings of studies of people drinking boiled, unfiltered coffee.

Whatever substance is responsible for this lipid raising effect it seems reasonable to conclude that filtering removes it. Regional and national differences in the effects of coffee on cholesterol concentration may therefore be explained by the brewing method. None of the more recent studies has incriminated caffeine.

But this is not the end of the story. A recent Norwegian study showed that coffee consumption strongly predicts coronary death, beyond what could be explained by its cholesterol raising effect. ${ }^{7}$ Coffee may therefore have other adverse effects on the cardiovascular system as yet unknown.

Two recent studies from the United States further complicate the matter. In the Kaiser Permanente study an increase in coronary risk was seen after prolonged follow up ${ }^{8}$ whereas in the health professional follow up study an increase was seen only for decaffeinated coffee. ${ }^{9}$ Different study designs may explain some of this discrepancy. The Kaiser Permanente study was completed before the health professionals follow up study, when more people were probably drinking unfiltered coffee. In the health professionals study consumers of decaffeinated coffee were older and may therefore have consumed more unfiltered coffee than the rest of the cohort. In this study the follow up was only two years. Before we can decide whether decaffeinated coffee increases the risk of heart disease longer studies with multiple assessments of exposure to decaffeinated and caffeinated coffee are needed.

Professor of Epidemiology,

DAG S THELLE

Nordic School of Public Health,

Box 12133,

S-402 42 Göteborg,

Sweden

1 Bak AAA. Coffee and cardiovascular risk: an epidemiological study [dissertation]. Rotterdam University of Rotterdam, 1990:1-159.

2 Førde $\mathrm{OH}, \mathrm{Knutsen} \mathrm{SF}$, Arnesen $\mathrm{E}$, et al. The Trømso heart study: coffee consumption and serum lipid concentrations in men with hypercholesterolaemia. A randomised intervention study. $B M \mathcal{J}$ lipid concentration

3 Aro A, Tuomilehto J, Kostianien E, et al. Boiled coffee increases serum low-density lipoprotein concentration. Metabolism 1987;36:1027-30

4 Bak AAA, Grobbee DE. The effect on serum cholesterol levels of coffee brewed by filtering or boiling. $N$ Engl f Med 1989;321:1432-7.

5 Bønaa K, Arnesen E, Thelle DS, Førde OH. Coffee and cholesterol: Is it all in the brewing? The Trømso study. BMf 1988;297:1103-4.

6 Zock PL, Katan MB, Merkus MP, van Dusseldorp M, Harryvan JL. Effect of a lipid-rich fraction from boiled coffee on serum cholesterol. Lancet 1990;335:1235-7.

7 Tverdal A, Stensvold I, Solvoll K, Foss OP, Lund-Larsen P, Bjartveit K. Coffee consumption and death from coronary heart disease in middle aged Norwegian men and women. BMf 1990;300: 566-9.

8 Klatsky AL, Friedman GD, Armstrong MA. Coffee use prior to myocardial infarction restudied: heavier intake may increase the risk. Am f Epidemiol 1990;132:479-88.

9 Grobbee DE, Rimm EB, Giovannucci E, Colditz G, Stampfer M, Willett W. Coffee, caffeine, and cardiovascular disease in men. N Engl f Med 1990;323:1026-32. 